\title{
INFLUENCE OF TREATED SEWAGE DISCHARGE ON THE BENTHOS CILIATE ASSEMBLY IN THE LOWLAND RIVER
}

\author{
WPŁYW ŚCIEKÓW Z OCZYSZCZALNI MIEJSKIEJ \\ NA STRUKTURE ZESPOŁU ORZĘSEK BENTOSOWYCH W RZECE NIZINNEJ
}

\begin{abstract}
This paper presents results of the studies of ciliate assemblage in benthos of lowland river influenced by sewage discharged from the municipal wastewater treatment plant. During the presented research the 47 ciliate species, including 45 species from the benthos of the river and 18 from the activated sludge of aeration chamber were identified. Only two species registered in the activated sludge were not observed in the river. Against the background of the lowest number of species in the point located in the distance of $50 \mathrm{~m}$ below the discharge of sewage the maximum amount and biomass of these species were observed. Whereas, $200 \mathrm{~m}$ below the discharge the decrease in number and biomass of ciliate to the level noted for location before the discharge was observed. Thus, generalizing, one may state that influence of municipal WWTP sewage discharge for ciliate assemblage in the river's benthos was clearly visible but local.
\end{abstract}

Keywords: river ecosystem, ciliates, assemblage structure, wastewater treatment plants, municipal sewage

\section{Introduction}

Most of water bodies are being influenced by various types of sewage discharged from point or dispersed sources. The amount of allochtone substances transported by sewages is increasing with the intensification of anthropogenic pressure. Although in the recent decades the wastewater treatment systems improved significantly, the older treatment technologies unable to provide the effective protection of water bodies from pollutant substances still continue to be widely used.

Usually, sewages contain the significant amounts of chemical compounds compromising the source of nutrient constituents for aquatic organisms, which results in eutrophication of water reservoirs [1-3]. The processes triggered by sewerage inflow often result in the reduction of oxygen concentration or in appearance of the deoxygenated zones

\footnotetext{
${ }^{1}$ Schmalhausen Institute of Zoology NAS of Ukraine, B. Khmelnytskogo 15, 01601 Kiev, Ukraine

${ }^{2}$ Sumy State University, Rimsky-Korsakov 2, 40007 Sumy, Ukraine

${ }^{3}$ Faculty of Environmental Engineering, Lublin University of Technology, ul. Nadbystrzycka 40B, 20-618 Lublin, Poland

${ }^{4}$ Faculty of Civil Engineering and Architecture, Lublin University of Technology, ul. Nadbystrzycka 40, 20-618 Lublin, Poland

* Corresponding author: z.suchorab@pollub.pl
} 
$[4,5]$. Herewith, the deterioration of aquatic environment results in changes of structure and functions of the aquatic communities [1, 6-8]. It was observed that discharge of even the properly treated sewerages may lead to the negative consequences for the water reservoirs related to the derogation of their self-purification abilities [1]. On the other hand, it is also necessary to take into account that wastewater can be discharged into the watercourse which has already been impoverished (degraded) and which biocenosis has been influenced by the other factors.

In order to perform the assessment of influence of the negative factors related to anthropogenic activity, including discharge of wastewater from the different types of wastewater treatment plants, the analyses of changes in communities of aquatic organisms may be applied. Different types of organisms, from bacteria [9], algae [10, 11] and protozoa $[12,13]$ to macroinvertebrates and vertebrates [14-18] are being used as indicators of changes in the aquatic environment. The significant influence of sewage on structure of the bacteria group was reported by Wakelin et al [8]. The increase in biomass of macrophytes and benthos invertebrates, as well as enhance of the biocenosis' respiration and primary production, related to wastewater discharge to the rivers close to Berlin (Germany) were observed [1]. Despite the fact that it is being usually accepted that influence of sewage on plankton organisms is not clear, Kushwaha and Agrahari [19] showed that their population decreased below wastewater discharge location to the Rapti River (Gorakhpur U.P. India). The studies concerning colonization of artificial substrates by algae and invertebrates performed for the Little Miami River (USA) showed that some part of species available in the river above the discharge point was absent on the substrates introduced to water below the discharge location [20]. At the same time there is evidence of the absence of imperceptible impact of sewage on macroinvertebrates and fish in the above mentioned river [21].

The proper selection of indicators group and their systematic and detailed studies are required to allow the adequate assessment of aquatic ecosystems' status. The significant diversity of organisms inhabiting aquatic environments and wide range of their tolerance allow making a choice of optimal objects for aquatic ecosystems' health monitoring. The protozoa, and especially ciliate, presenting the huge species diversity and available nearly in all settlements [22, 23] are treated as good indicators of changes in ecosystems [24-28]. Moreover, ciliate are present in the maximally wide range of the saprobic scale, from poli-saprobic zone to environments of very low concentration of organic substances, the oligo- and xeno-saprobic zone [12, 13]. Madoni and Zangrossi [29], during analysis of long-term changes in the river below and above point of sewages discharge demonstrated the presence of changes in the trophic structure of ciliate community.

The influence of sewages discharge from the municipal WWTP of Sumy (Ukraine) on the structure of benthic ciliate assemblage in the Psel River was analyzed in the presented studies. The changes in ciliate assemblage influenced by the constant inflow of treated sewages were analyzed in comparison to these organisms assembly structure in the activated sludge from the aeration chambers of Sumy WWTP.

\section{Materials and methods}

\section{Sampling site}

Three series of samples were collected in April 2016 from the left tributary of the Dnieper, the Psel River. It is the lowland river with the length of $717 \mathrm{~km}$, which runs 
mainly through agricultural areas and also receives treated and untreated sewage from settlements. The samples were taken in the in the middle reaches of the river downstream of the Sumy city (Ukraine). The Psel River receives effluents from the municipal wastewater treatment plant (WWTP), which provides mechanical and biological treatment with the use of aeration tanks, unable to provide the effective removal of nitrogen and phosphorus compounds. So, over the past 10 years in the Psel River at the sampling site the exceeding of permissible level of phosphates and nitrogen compounds was permanently recorded.

Sampling station No 1 was located at $200 \mathrm{~m}$ above the place of sewage effluent discharge. Bottom sediments at this site are formed by silty sand. Sampling station No 2 was located $50 \mathrm{~m}$ below the sewage discharge. Bottom sediments at this station were consisting of black silt. Finally, sampling station No 3 was $200 \mathrm{~m}$ below the place of discharge of sewage. Bottom sediments were the heavily silty sand. The samples of activated sludge from Sumy municipal wastewater treatment plant for comparison with the samples from the Psel River were also taken.

All sampling points were located downstream of the Sumy city, so in this section the river was affected by runoff from the territory of the Sumy city as well from the suburban settlements and agricultural areas. Also the river's water regime was affected by the hydropower plant dam, located downstream.

\section{Sampling and counting of protozoa}

Samples of bottom substrate were taken with the use of microbenthometer, from the depth of 0.8-1.0 $\mathrm{m}$ in the coastal zone. Samples of activated sludge were collected from the aeration tank at the Sumy municipal WWTP.

Quantitative analysis of samples was performed in the laboratory within the sampling day. In most cases, ciliates were identified in vivo. When necessary, cells were stained with the use of $1 \%$ methyl green or silver nitrate [30]. Estimation of population density were carried out by enumerations in $25 \mathrm{~mm}^{3}$ subsamples, extracted with micropipette, as described by Madoni [31]. The numbers of repeated enumerations were 5 for the samples of activated sludge and 11 for the bottom sediments. Species identification was based on [12, 13, 32-34]. Saprobic evaluations were performed using the saprobic values given by Sladecek [35], as revised by Foissner et al [12, 13].

Analysis of variance (ANOVA) and post-hoc Tukey HSD (Honestly Significant Difference) test were performed to obtain $p$-values for pairwise differences in biomasses and for pairwise differences in ciliate's densities between sampling stations and the activated sludge. Both functions - aov and Tukey HSD - which were used for calculations are from $\mathrm{R}$ package stats [36]. Past software, version 1.57 was used for calculation of ecological indices as well as for performing cluster and principal components analysis [37].

The following ecological indices, being the measure of biodiversity of the ciliate assemblage were calculated: Shannon diversity index $(\mathrm{H})$, Margalef index, dominance index (D) and equitability $\mathbf{J}$ index [38], which indices are often applied for activated sludge analysis [39].

\section{Results and discussion}

Sewage discharge to the river affects the quality of bottom sediments which may be determined by their chemical and particle composition. The organic and inorganic compounds originated from sewage may be cumulated in the bottom sediments [9]. Even 
discharge of the treated sewage may increase the concentration of TOC, $\mathrm{P}$ and $\mathrm{N}$ in the bottom sediments [1]. Thus, the benthic organisms, reflecting the dynamics of environment's quality changes may be good indicators of the local effects of sewage on the river.

Table 1

List of species of ciliates in Psel River and activated sludge from sewage treatment plants in the Sumy City

\begin{tabular}{|c|c|c|c|c|c|}
\hline Species & Code & $\begin{array}{c}\text { Activated } \\
\text { sludge }\end{array}$ & Station 1 & Station 2 & Station 3 \\
\hline Acineria uncinata & 9 & + & & + & + \\
\hline Acineta ornata & 21 & + & & + & + \\
\hline Aspidisca cicada & 1 & + & & + & + \\
\hline Aspidisca lynceus & 2 & & + & & \\
\hline Balanophrya sp. & 45 & & + & & + \\
\hline Bursella truncata & 23 & & + & & \\
\hline Carchesium polypinum & 10 & + & & + & \\
\hline Chilodonella uncinata & 3 & + & & & \\
\hline Chilodontopsis sp. & 4 & + & & & \\
\hline Cinetochilum margaritaceum & 24 & & + & & \\
\hline Cyclidium glaucoma & 25 & & + & + & \\
\hline Dexiostoma compilum & 26 & & & & + \\
\hline Epistylis longicaudatum & 13 & + & & + & \\
\hline Epistylis coronata & 11 & + & & + & \\
\hline Epistylis entzii & 12 & + & & + & \\
\hline Euplotes patella & 5 & & + & & \\
\hline Euplotopsis affinis & 6 & + & & & \\
\hline Frontonia angusta & 27 & & + & & \\
\hline Frontonia leucas & 28 & & + & & + \\
\hline Hexotricha caudata & 29 & & & + & \\
\hline Holophrya discolor & 42 & + & & & \\
\hline Loxodes striatus & 30 & & + & & \\
\hline Metopus es & 31 & & & & + \\
\hline Microthorax pusillus & 7 & & & & + \\
\hline Opercularia articulata & 14 & & & + & + \\
\hline Opercularia coarctata & 15 & & & + & + \\
\hline Paramecium caudatum & 32 & & + & + & + \\
\hline Phialina pupula & 43 & & & + & \\
\hline Plagiocampa rouxi & 33 & + & & + & + \\
\hline Pleuronema coronatum & 34 & & + & & \\
\hline Prorodontida Gen. $\mathrm{sp}$. & 35 & & + & & \\
\hline Pseudocohnilembus pusillus & 36 & & + & & + \\
\hline Pseudovorticella elongata & 16 & + & & & \\
\hline Spirostomum minus & 37 & & + & & \\
\hline Stentor coeruleus & 44 & & + & & \\
\hline Tachysoma pellionellum & 38 & & & & + \\
\hline Thigmogaster sp. & 8 & & & + & \\
\hline Tokophrya quadripartita & 22 & + & & & \\
\hline Uronema nigricans & 39 & & + & & + \\
\hline Urotricha farcta & 40 & & + & & + \\
\hline Urotricha ovata & 41 & & + & & \\
\hline Vorticella aquadulcis & 17 & + & & & \\
\hline Vorticella convallaria & 18 & + & + & & \\
\hline Vorticella infusionum & 19 & + & & & \\
\hline Vorticella microstoma & 20 & + & & + & \\
\hline
\end{tabular}


Earlier the bottom of the Psel River mainly was sandy, but now when the river is polluted, the bottom is usually covered by the silty sands. Dirty sand is a prevailing biotope at the bottom at the point No 1 located $200 \mathrm{~m}$ before the discharge location. Similar dirty sand was on the bottom at point No 3, located $200 \mathrm{~m}$ below. While, at the bottom of the rivet at point No 2, $50 \mathrm{~m}$ below the sewage discharge location, the sand was covered by the thick layer of black mud, which had structure similar to the activated sludge.

During our research performed within bottom sediments for the three points at the Psel River 45 species of ciliate were identified. They are presented in Table 1 (+ means occurrence of species in particular measurement station).

The 18 species were observed inside the activated sludge sampled of WWTP discharging treated sewage to the tested river. What is important, that 16 of 18 species of activated sludge were also found in the river. Also, it should be noticed that in the course of our studies there were no significant difference in the number of ciliate species in the bottom sediments after the point of effluent discharge.

So, at point No 1, $200 \mathrm{~m}$ above the discharge, 19 species were found, and at points No 2 and No 3, 50 and $200 \mathrm{~m}$ below sewage discharge, 16 and 18 species were available, respectively. But in these same points the ciliate abundances differed clearly (Fig. 1a).
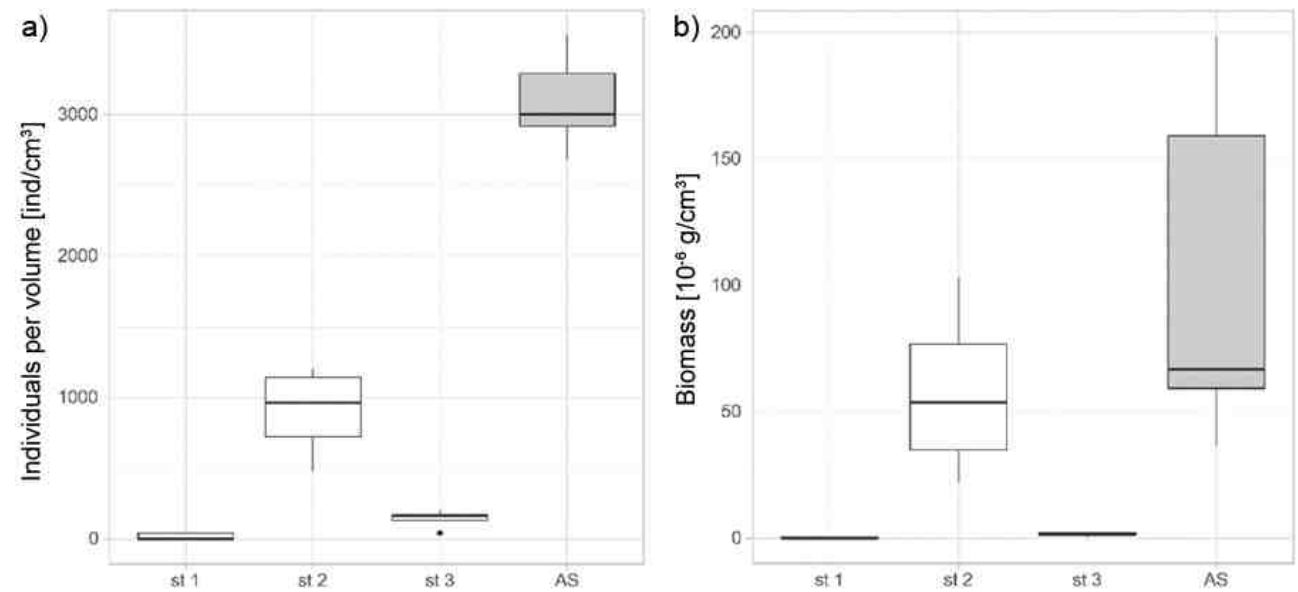

Fig. 1. Ciliate abundance (a) and biomass (b) in the bottom sediments at three sampling stations at Psel River and in the activated sludge. st. 1 (station) - bottom sediments at $200 \mathrm{~m}$ above the sewages discharge; st. 2 - bottom sediments at $50 \mathrm{~m}$ below the sewages discharge; st. 3 - bottom sediments at $200 \mathrm{~m}$ below the sewages discharge; AS - activated sludge from Sumy WWTP

The graphs presented in Figure 1 allow to conclude that the ciliate abundance under the artificial conditions of the activated sludge is significantly higher than their abundance under the conditions of the natural water reservoir. This effect is the result of energetic subsidies in the form of organic matter and air injection. The influence of energetic subsidies introduced by sewage is clearly visible at the place located $50 \mathrm{~m}$ below the sewage discharge point.

Similar response of testate amoebae, namely the increase abundances at impacted sampling stations in conditions with the higher nutrient concentrations and the lower oxygenation levels was observed by Correa et al [40]. 
According to one-way ANOVA analysis between the total abundance of ciliate at the all tested points in the river and in the studied activated sludge there were noted the significant differences for the $95 \%$ confidence interval. The only statistically insignificant difference $(p=0.8659)$ was observed between points No 1 and No 3. Thus, already $200 \mathrm{~m}$ below the sewage discharge the quantitative structure of ciliate assemblages was similar to the structure typical for the section of the river above the discharge point of sewages from Sumy municipal WWTP.

The increase in ciliate biomass, observed in the bottom sediments $50 \mathrm{~m}$ below the sewages discharge in the Psel River, which reflects their reaction on the energetic subsidies, is shown in Figure 1b. Determination of statistical differences $(p)$ between ciliate biomass in the activated sludge and sampling point No 1 and No 3 showed the significant differences for $95 \%$ confidence interval ( $p=0.0084$ and $p=0.0146$, respectively). On the other hand, the insignificant difference was observed between biomass of ciliate in the activated sludge and in the bottom sediments at sampling point No $2(50 \mathrm{~m}$ below the sewage discharge location), $p=0.4346$. It proves the local influence of sewage on the organisms inhabiting the river bottom sediments. The increase in benthic invertebrate biomasses as a result of wastewater discharge was noted in [1]. According to the results of our experiment, in the Psel River the effect of the sewages discharge on bottom ciliate assemblage was limited by the distance less than $200 \mathrm{~m}$ from the discharge point.

The graph presented in Figure 2 shows that determination of the similarity between the all sampling points, based on the ciliate species composition and their abundance allowed to partition them into two clusters. The first cluster grouped two sampling points, No 1 and No 3, located in the studied river at $200 \mathrm{~m}$ above and $200 \mathrm{~m}$ below the sewages discharge, and the second one grouped the activated sludge and sampling point No 2, closest to the sewages discharge. Thus, the strong local influence of sewage on the ciliate assembly, at least at the distance of $50 \mathrm{~m}$ below the discharge point was confirmed.

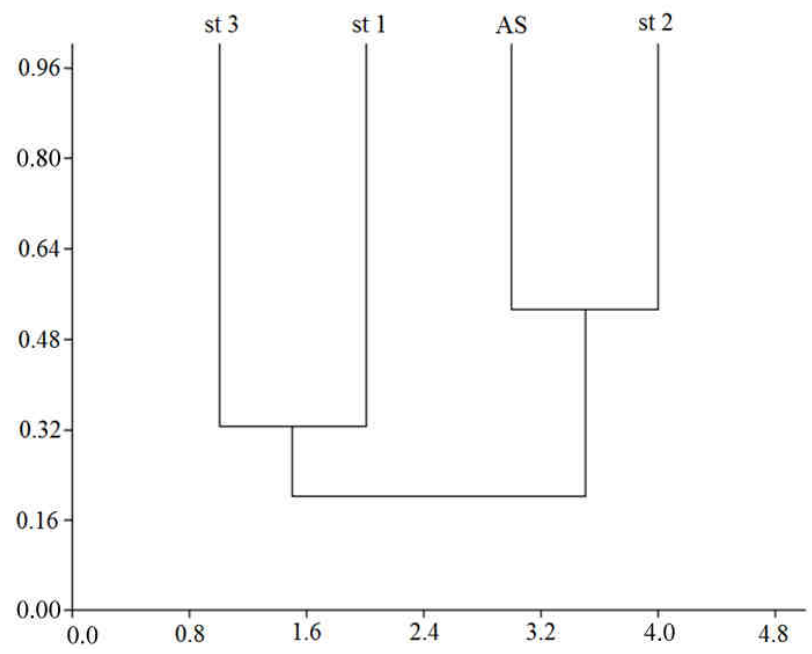

Fig. 2. Dendrogram of the similarity of ciliate assemblages from three sampling stations at Psel River and from the activated sludge (Simpson index, algorithm: paired group). st.1 - bottom sediments at $200 \mathrm{~m}$ above the effluent; st. 2 - bottom sediments at $50 \mathrm{~m}$ below the effluent; st. 3 - bottom sediments at $200 \mathrm{~m}$ below the effluent; AS - activated sludge from Sumy WWTP 
The observed change in the dominant species groups at different sampling points was demonstrative. At sampling point No 1 the most numerous species were Cyclidium glaucoma (Muller, 1773) and Pseudocohnilembus pusillus (Quennerstedt, 1869) At sampling point No 2 below discharges there were Aspidisca cicada (Muller, 1786), Acineria uncinata (Tucolesco, 1962) and Epistylis coronata (Nusch, 1970). Almost the same set of dominant species was observed in the activated sludge - A. uncinata and A. cicada. At sampling point No 3 among dominant species A. cicada was conserved and $P$. pusillus, which was among the dominants at sampling point No 1, reappeared.

PCA method showed that the majority of identified species at $95 \%$ confidence level are tolerant to high levels of pollution and constitute a single assembly visible at Figure 3.

The common species of the activated sludge are located at the top of the positive part of axes 2 in the plot. The species which do not occur to the active sludge are settled in the bottom of the negative part of the plot.

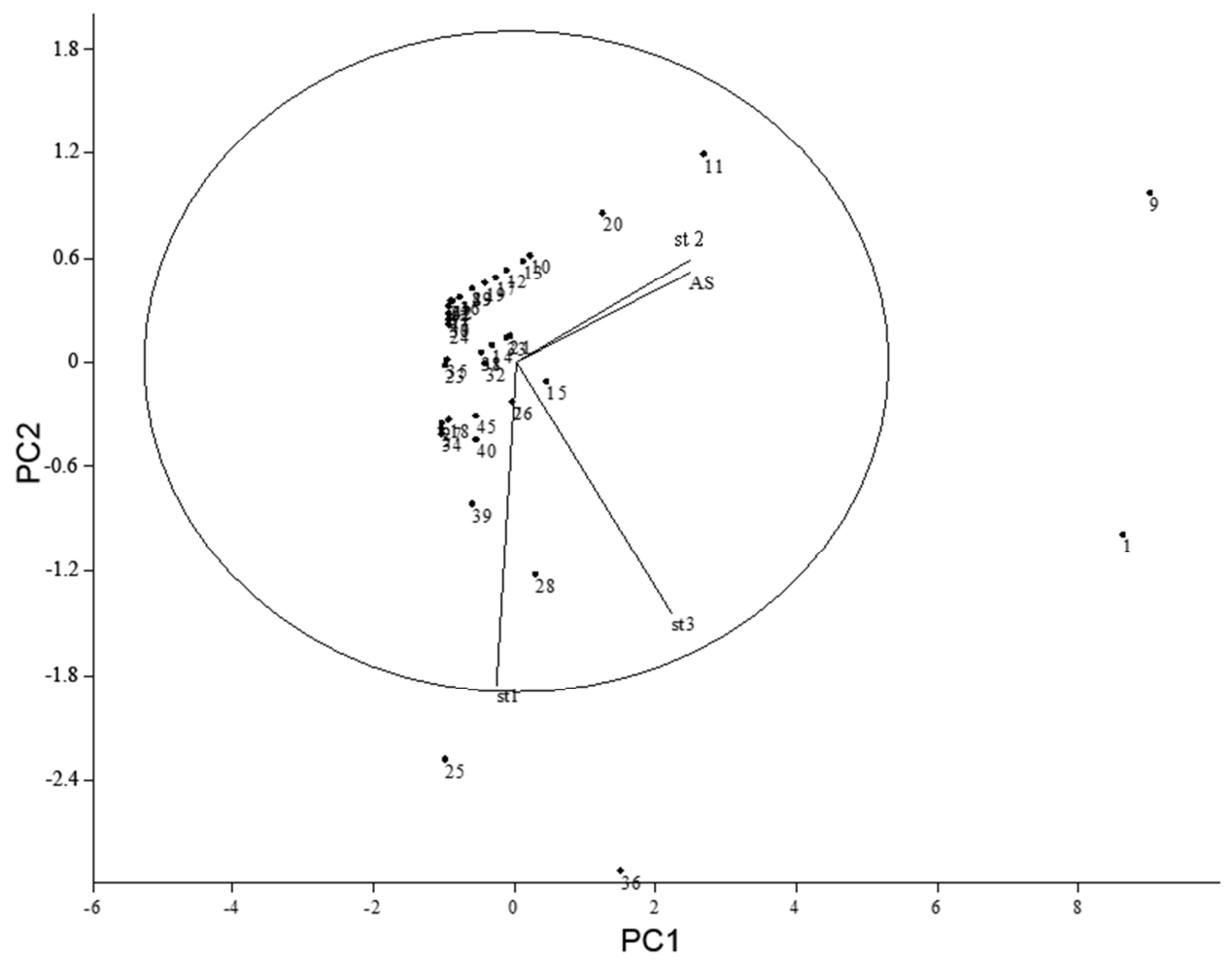

Fig. 3. PCA ordination diagram of the biomass data for 45 ciliate species at four states

Such separation may be caused by the fact that species common in the activated sludge could not realize their productive potential in the river conditions. At the same time, the other species were observed only in the river conditions. These are mainly the species, which are not commonly observed in the active sludge but are widespread in the polluted rivers and lakes. Also, it is worth mentioning here, that that four of the species from analysed communities appear behind the area of $95 \%$ confidence level. Two of them are 
mainly connected with condition of activated sludge: Acineria uncinata (9), Aspidisca cicada (1) - higher position in the plot, and two are typical for surface water: Pseudocohnilembus pusillus (36), Cyclidium glaucoma (25) - bottom part of plot.

Intensity of influence caused by the regular sewages discharge on the ciliate assemblage in the bottom sediments may be additionally assessed with the use of diversity indices and saprobity [35, 38, 41, 42]. There are contrary literature reports concerning the influence of sewages on the diversity of aquatic organisms and ecosystems. For instance, Drury et al [9] assumed that WWTP sewages have the potential to reduce the natural diversity existing among the river ecosystems and may result in the biotic homogenization. The same opinion was presented in paper by Madoni [43] where the increase in the similarity among the different sections of the river influenced by the pollutants originated to sewages was observed. On the other hand, Lewis [20] stated, that the Shannon index and similarity indices such as coefficient of community and index C-lambda calculated on the basis of protozoa abundance presented minor changes when affected by municipal wastewaters. Thus, we checked the values of some indices characterizing the diversity of bottom ciliate assemblages at the selected section of the river influenced by sewages and in the activated sludge.

The performed analysis of indices describing the structure of ciliate assembly in the Psel River showed that different indices presented various susceptibility levels to the analyzed factor. The influence of sewage discharge on ciliate assemblage in the bottom sediments was visible at the point located $50 \mathrm{~m}$ below the sewage discharge point. It is visible in Figure 4a that the appearance of sewages in the river slightly changed their equitability and domination level in their structure, as related to the clearly low equitability and increased domination of ciliate from the activated sludge.
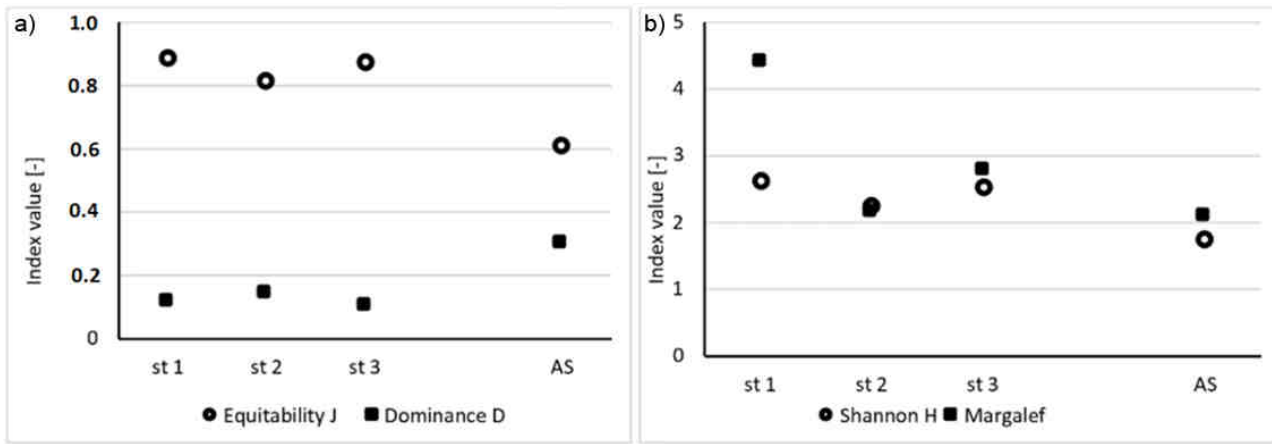

Fig. 4. Equitability index $\mathrm{J}$ and dominance index D (a), Shannon diversity index $H$ and Margalef's index (b) of ciliate assemblages in Psel River and in the activated sludge. st. 1 - bottom sediments at $200 \mathrm{~m}$ above the effluent; st. 2 - bottom sediments at $50 \mathrm{~m}$ below the effluent; st. 3 - bottom sediments at $200 \mathrm{~m}$ below the effluent; AS - activated sludge from Sumy WWTP

Similarly to the dominance and equitability indices the Shannon index (Fig. 4b) shows a negligible impact of sewage on the structure of ciliate assemblage. Three named indices nearly showed no differences between the structures of ciliate assemblage at points before and after the effluent discharge. On the contrary, there was the quite substantial difference observed in the ciliate species composition. The Margalef index confirmed these deeper changes in the structure of ciliate assemblage below sewage discharge. 
The saprobic index calculated on the ciliates, was within 2.9-3.1 in all samples (including activated sludge), which corresponds to an alpha-mesosaprobic level of organic pollution.

It is obvious that the impact of treated sewage on the water body is largely determined by the proper operation of treatment facilities and the degree of wastewater treatment. In this study, the evaluation of the activated sludge from Sumy WWTP was performed using Madoni biotic index [31]. According to the received results, the quality of the activated sludge treatment plant in Sumy was indicated as "high" according to the maximum observed value of sludge biotic index $(\mathrm{SBI}=10)$. It can be argued that the composition of prevailing in the number of ciliated protozoa and other organisms was similar as in the activated sludge from the advanced biological nutrient removing wastewater treatment plant Hajdow, Lublin [44, 45]. Despite the fact that the activated sludge in WWTP Sumy was of high-quality, the introduction of energetic subsidies as additional quantities of primarily nitrogen and phosphorus compounds was not limited, which was recorded in the increased levels in the receiving river below sewage discharge, as well as by the increased $\mathrm{BOD}_{5}$. Accordingly, such conditions caused the observed difference in the composition of benthic ciliate assemblage above and below the sewage discharge.

\section{Conclusions}

This paper presents the performed analysis of influence of treated wastewater discharge from municipal WWTP in Sumy, Ukraine, on the bottom ciliate assemblages in the Psel River. The changes in tested groups' structures, affected by the discussed factor, were related to the situation observed for groups above the discharge point and to structure of ciliate group inside the aeration chamber of wastewater treatment plant. During the performed research the ciliate abundance and their biomass for each sampling points were tested. On the basis of these indicators the clear influence of sewages discharge on ciliate groups directly below the inflow and its stabilization after the distance of $200 \mathrm{~m}$ were determined. The similar tendency was noted during analysis of domination, equitability and diversity indices. Only the Margalef index value suggested lacking the total stabilization of ciliate groups at the point $200 \mathrm{~m}$ below the discharge and return to the conditions observed before the sewage inflow.

It may be also assumed that if the quality of the aquatic environment of the tested river had not been affected by the dispersed sewages (runoff from the territory of Sumy town as well from surrounding areas), the reaction of analyzed aquatic organisms would have been more clear.

\section{References}

[1] Gücker, B, Brauns M, Pusch MT. Effects of wastewater treatment plant discharge on ecosystem structure and function of lowland streams. J N Am Benthol Soc. 2006;25:313-329. DOI: 10.1899/0887-3593(2006)25[313:EOWTPD]2.0.CO;2.

[2] Smith VH, Tilman GD, Nekola JC. Eutrophication: Impacts of excess nutrient inputs on freshwater, marine, and terrestrial ecosystems. Environ Pollut. 1999;100(1-3):179-196. DOI: 10.1016/S0269-7491(99)00091-3.

[3] Strom PF, Matulewich VA, Finstein MS. Concentrations of nitrifying bacteria in sewages, effluents and a receiving stream and resistance of these organisms to chlorination. Appl Environ Microbiol. 1976;31:731-737. http://aem.asm.org/content/31/5/731.full.pdf.

[4] Courchaine RJ. Significance of nitrification in stream analysis: effects on the oxygen balance. J Water Pollut Control Fed. 1968;40:835-847. http://www.jstor.org/stable/25036332. 
[5] Rueda J, Camacho A, Mezquita F, Hernandez R, Roca JR. Effects of episodic and regular sewage discharges on the water chemistry and macroinvertebrate fauna of a Mediterranean stream. Water Air Soil Pollut. 2002;140:425-444. DOI: 10.1023/A:1020190227581.

[6] Dyer SD, Peng C, McAvoy DC, Fendinger NJ, Masscheleyn P, Castillo LV, et al. The influence of untreated wastewater to aquatic communities in the Balatuin River, The Philippines. Chemosphere. 2003:52:43-53. DOI: 10.1016/S0045-6535(03)00269-8.

[7] Spänhoff B, Bischof R, Böhme A, Lorenz S, Neumeister K, Nöthlich A, et al. Assessing the impact of effluents from a modern wastewater treatment plant on breakdown of coarse particulate organic matter and benthic macroinvertebrates in a lowland river. Water Air Soil Pollut. 2007;180:119-129. DOI: 10.1007/s11270-006-9255-2.

[8] Wakelin SA, Colloff MJ, Kookana RS. Effect of wastewater treatment plant effluent on microbial function and community structure in the sediment of a freshwater stream with variable seasonal flow. Appl Environ Microbiol. 2008;74(9):2659-2668. DOI: 10.1128/AEM.02348-07.

[9] Drury B, Rosi-Marshall E, Kelly JJ. Wastewater treatment effluent reduces the abundance and diversity of benthic bacterial communities in urban and suburban rivers. Appl Environ Microbiol. 2013;79(6):1897-905. DOI: 10.1128/AEM.03527-12.

[10] Rajfur M, Klos A, Waclawek M. Algae utilization in assessment of the large Turawa Lake (Poland) pollution with heavy metals. J Environ Sci Health. Part A. 2011;46(12):1401-1408. DOI: 10.1080/10934529.2011.606717.

[11] Rajfur M, Klos A. Use of algae in active biomonitoring of surface waters. Ecol Chem Eng S. 2014;21(4):561-576. DOI: 10.1515/eces-2014-0040.

[12] Berger H, Foissner W. Illustrated guide and ecological notes to ciliate indicator species (Protozoa, Ciliophora) in running waters, lakes, and sewage plants. In: Steinberg C, editor. Handbuch Angewandte Limnologie. Ecomed Verlag; 2003. DOI: 10.1002/9783527678488.hbal2003005.

[13] Serrano S, Arregui L, Perez-Uz B, Calvo P, Guinea A. Guidelines for the Identification of Ciliates in Wastewater Treatment Plants. 2008. London: IWA Publishing. http://www.iwapublishing.com/ books/9781843391715/guidelines-identification-ciliates-wastewater-treatment-plants.

[14] Carter JL, Resh VH, Hannaford MJ, Myers MJ. Macroinvertebrates as biotic indicators of environmental quality. In: Hauer FR, Lamberti GA, editor. Methods in Stream Ecology. Amsterdam: Academic Press; 2006;805-833. https://sdp2013.files.wordpress.com/2013/12/bahan-bacaan-dr-bu-maya-methods-in-streamecology.pdf.

[15] Wright IA, Chessman BC, Fairweather PG, Benson LJ. Measuring the impact of sewage effluent on the macroinvertebrate community of an upland stream: the effect of different levels of taxonomic resolution and quantification. Aust J Ecol. 1995;20:142-149. DOI: 10.1111/j.1442-9993.1995.tb00528.x.

[16] EU Water Framework Directive 2000/60/EC. http://ec.europa.eu/health/endocrine_disruptors/ docs/wfd_200060ec_directive_en.pdf.

[17] Kominkova D, Stransky D, St'astna G, Caletkova J, Nabelkova J, Handova Z. Identification of ecological status of stream impacted by urban drainage. Water Sci Technol. 2005;51(2): 249-256. http://wst.iwaponline.com/content/51/2/249.

[18] Gorzel M, Kornijow R. The response of zoobenthos to "natural channelization" of a small river. Ecohydrol Hydrobiol. 2007;7(1):59-70. DOI: 10.1016/S1642-3593(07)70189-1.

[19] Kushwaha VB, Agrahari M. Effect of domestic sewage on zooplankton community in River Rapti at Gorakhpur, India. World J Zool. 2014;9(2): 86-92. DOI: 10.5829/idosi.wjz.2014.9.2.83293.

[20] Lewis MA. Impact of municipal wastewater effluent on water quality, periphyton, and invertebrates in the Little Miami River Near Xenia, Ohio. Ohio J Sci. 1986;86(1):2-8. http://hdl.handle.net/1811/23110.

[21] Wynes D, Wissing T. Effects of water quality on fish and macroinvertebrate communities of the Little Miami River. Ohio J Sci. 1981;81:259-267. http://hdl.handle.net/1811/22809.

[22] Corliss JO. Biodiversity and biocomplexity of the protists and an overview of their significant roles in maintenance of our biosphere. Acta Protozool. 2002;41:199-219. http://www1.nencki.gov.pl/pdf/ ap/ap636.pdf.

[23] Finlay BJ, Esteban GF. Freshwater protozoa: biodiversity and ecological function. Biodivers Conserv. 1998;7:1163-1186. DOI: 10.1023/A:1008879616066.

[24] Yun-Fen S, Buikema AL Jr, Yongue WH Jr, Pratt JR, Cairns J Jr. Use of protozoan communities to predict environmental effects of pollutants. J Protozool. 1986;33:146-151. DOI: 10.1111/j.1550-7408.1986.Tb05579.x.

[25] Lynn DH, Gilron GL. A brief review of approaches using ciliated protists to assess aquatic ecosystem health. J Aquat Ecosyst Health. 1992;1(4):263-270. DOI: 10.1007/BF00044168.

[26] Lawrence JR, Swerhone GDW, Wassenaar LI, Neu TR. Effects of selected pharmaceuticals on riverine biofilm communities. Can J Microbiol. 2005;51:655-669. DOI: 10.1139/w05-047. 
[27] Madoni P. Ciliated protozoa and water quality in the Parma River (Northern Italy): long-term changes in the community structure. Hydrobiologia. 1993;264(3):129-135. DOI: 10.1007/BF00007283.

[28] Stout JD. Reactions of ciliates to environmental factors. Ecology. 1956;37(1):178-191. http://www.jstor.org/stable/1929681.

[29] Madoni P, Zangrossi S. Ciliated protozoa and saprobical evaluation of water quality in the Taro River (northern Italy). Ital J Zool. 2005;72:21-25. DOI: 10.1080/11250000509356648.

[30] Foissner W. Basic light and scanning electron microscopic methods for taxonomic studies of Ciliated Protozoa. Europ J Protistol. 1991;27:313-330. DOI: 10.1099/ijs.0.057893-0.

[31] Madoni P. A sludge biotic index (SBI) for the evaluation of the biological performance of activated sludge plants based on the microfauna analysis. Water Res. 1994;28:67-75. DOI: 10.1016/0043-1354(94)90120-1.

[32] Foissner W, Berger H. A user-friendly guide to the ciliates (Protozoa, Ciliophora) commonly used by hydrobiologists as bioindicators in rivers, lakes, and waste waters, with notes on their ecology. Freshwater Biol. 1996;35:375-482. DOI: 10.1111/j.1365-2427.1996.tb01775.x.

[33] Warren A. A revision of the genus Vorticella (Ciliophora: Peritrichida). Bull Br Mus Nat Hist (Zool). 1986;50(1):1-57. https://archive.org/details/biostor-39.

[34] Warren A. A revision of the genus Pseudovorticella Foissner \& Schiffmann, 1974 (Ciliophora: Peritrichida). Bull Br Mus Nat Hist (Zool). 1987;52(1):1-12. http://biostor.org/reference/11911.

[35] Sladecek V. System of water quality from the biological point of view. Arch Hydrobiol Ergeb Limnol. 1973;7:1-217. DOI: 10.1002/iroh.19740590412.

[36] R Core Team. 2015. R: A language and environment for statistical computing. Vienna: R Foundation for Statistical Computing. https://www.R-project.org/.

[37] Hammer $\varnothing$, Harper DAT, Ryan PD. PAST: Paleontological statistics software package for education and data analysis. Palaeo Electron. 2001;4(1):1-9. http://palaeo-electronica.org/2001_1/past/issue1_01.htm.

[38] Magurran AE. Measuring Biological Diversity. Oxford: Blackwell Science; 2003;1-264. http://eu.wiley.com/ WileyCDA/WileyTitle/productCd-0632056339.html.

[39] Babko R, Kuzmina T, Jaromin-Gleń K, Bieganowski A. Bioindication assessment of activated sludge adaptation in a lab-scale experiment. Ecol Chem Eng S. 2014;21(4):605-616. DOI: 10.1515/eces-2014-0043.

[40] Corrêa LVA, Hardoim EL, Zeilhofer P. Is the periphytic structure of Testaceans (Protozoa: Rhizopoda) related to water quality: a case study in the Cuiabá River, Brazil. Appl Ecol Env Res. 2015;13(1):85-97. DOI: 10.15666/aeer/1301_085097.

[41] Lagod G, Chomczynska M, Montusiewicz A, Malicki J, Bieganowski A. Proposal of measurement and visualization methods for dominance structures in the saprobe communities. Ecol Chem Eng S. 2009;16(3):369-377. http://tchie.uni.opole.pl/freeECE/S_16_3/LagodChomczynska_16(3).pdf.

[42] Chomczynska M, Montusiewicz A, Malicki J, Lagod G. Application of saprobes for bioindication of wastewater quality. Environ Eng Sci. 2009;26(2): 289-295. DOI: 10.1089/ees.2007.0311.

[43] Madoni P. Ciliated protozoa and water quality in the Parma River (Northern Italy): long-term changes in the community structure. Hydrobiologia. 1993;264:129-135. DOI: 10.1007/BF00007283.

[44] Babko R, Łagód G, Jaromin-Gleń KM. Abundance and structure of ciliated protozoa community at the particular devices of "Hajdów" WWTP. Rocznik Ochr Środ. 2012;14:56-68. http://old.ros.edu.pl/text/ pp_2012_002.pdf.

[45] Jaromin-Gleń K, Babko R, Łagód G, Sobczuk H. Community composition and abundance of protozoa under different concentration of nitrogen compounds at "Hajdow" wastewater treatment plant. Ecol Chem Eng S. 2013;20(1):127-139. DOI: 10.2478/eces-2013-0010. 